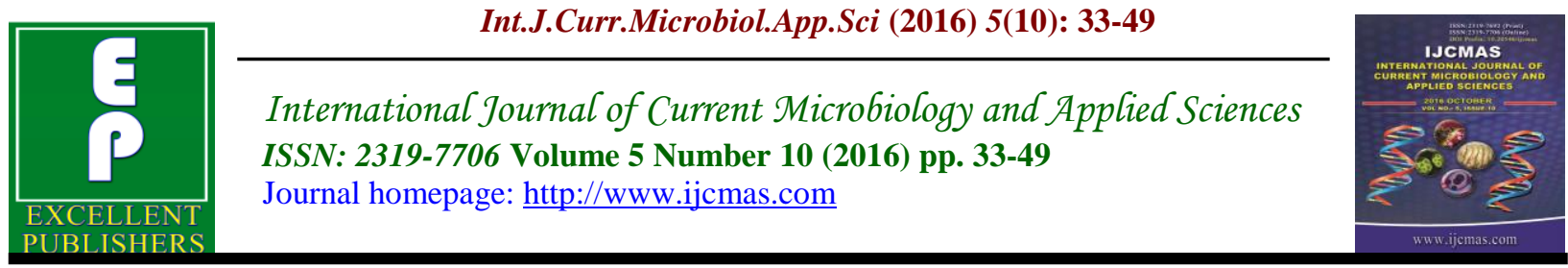

Original Research Article

http://dx.doi.org/10.20546/ijcmas.2016.510.006

\title{
Spatial and Seasonal Variation of Macrobenthos from Puducherry Coast, Southeast Coast of India
}

\author{
K. Balachandar*, A. Sundaramanickam and S. Kumaresan \\ Centre of Advanced Study in Marine Biology, Faculty of Marine Sciences, Annamalai \\ University, Parangipettai 608 502, Tamilnadu, India \\ *Corresponding author
}

Keywords

Puducherry, Capitella capitata, Total organic carbon, Clay.

\begin{tabular}{l}
\hline Article Info \\
\hline Accepted: \\
12 September 2016 \\
Available Online: \\
10 October 2016
\end{tabular}

\section{A B S T R A C T}

Seasonal variations on benthic diversity and its relationship with sedimentary parameters were carried out at different locations of Puducherry estuary and coast which are heavily sewage and polluted region at Puducherry. The values of sediment TOC (Total Organic Carbon) was found to have ranged from $0.75 \mathrm{mgC} / \mathrm{g}$ to $13.26 \mathrm{mgC} / \mathrm{g}$ and the maximum percentage of clay, silt and sand were recorded as $81.54 \%, 43.90 \%$ and $94.21 \%$ from the stations PDY-I, PDY-VI \& PDY-III respectively. The value of benthic faunal density was found varied from 450-2250 Nos $/ \mathrm{m}^{2}$ with maximum in station PDY-VI and minimum in PDY-III. In station PDY-VI was registered with highest species diversity index in the range of 3.735 and 5.266. The domination of particular polychaete species such as Capitella capitata, Cossura coasta, Nephtys dibranchis and Nereis capensis was found in estuary (PDY-I and PDY-II) because these species were found to withstand for the direct impact of organic and inorganic pollution. A significant discrimination of species composition was noticed on the benthic population between estuary and coast due to the differential in exposure by the macrobenthos for the pollutants. The present studies recommend that the above polychaete species can be considered as indicator species for organic pollution.

\section{Introduction}

Macrobenthic invertebrates are an extremely important part of the marine ecosystem (Macdonald et al., 2012). Over the 95\% of the known marine species are considered benthic. These include epifauna which live on or move over the surface of a substrate (Tagliapietra and Sigovini 2010). They have the ability to attach to the firm substrate and/or can move freely along the seafloor. The other group belongs to the infauna, inhabitants that live within the sediments instead on the bottom sediments (Tagliapietra and Sigovini, 2010 and Smith and Smith, 2006).

Diversity, distribution and abundance of macrobenthos depend on the characteristics of their environment such as pollution condition, organic matter, content, soil texture and sediment (Dahanayakar et al., 
2006). Because they alter in their adjustment to environmental conditions and their tolerance of or sensitivity to contamination, the parameters of benthic animals (such as their community structure, dominant species, variety and abundance) can be utilized to reflect environmental quality (Gao, 2011).

Frequently, there is a positive correlation between organic carbon and the contaminant level in estuary and coastal sediments. Content of organic carbon (TOC) in the sediment can be an indicator of pollution (Shine and Wallace, 2000; Hyland et al., 2005). Analysis of benthic macrofaunal communities and associated environmental variables, such as TOC of sediment, are important tools for assessing the health of estuary and coastal marine environments (Magni, 2003). There is a need for versatility in the use of indicators of biological change, in order to compensate for the effects of local variability in natural and anthropogenic sources of disturbance (Rees et al., 2005).

Anthropogenic activities in the coastal area of puducherry many industrial and sewage, explicitly Sea include, urban effluent which houses many refineries and petro-chemical industries from and fishing and shipping $\left(\mathrm{O}^{*}\right.$ ztu" rk et al., 2000). The benthic environment is a fundamental compartment of any aquatic ecosystem. Bottom sediments are the final sink for many anthropogenic contaminants and they can accumulate great amounts of organic matter affecting the oxygen content of the bottom water (Venturini et al., 2004). Different groups of macro invertebrates have different tolerances to pollution, which means they can serve as useful indicators of water quality (Alexander et al., 2007). These organisms are differently sensitive to fluctuations of many biotic and abiotic factors. Such organisms have specific requirements in terms of physical and chemical conditions. Consequently, the changes in the macro invertebrates' community structure have been commonly used as an indicator of the condition of an aquatic system (Armitage et al., 1983). Changes in the presence or absence, numbers, morphology, physiology or behavior of these organisms can indicate that the physico-chemical conditions of the water are beyond their preferred units (Kenney et al., 2009).

Anthropogenic stress is the response of biological entity, of any individual, population, or community, to an anthropogenic disturbance. This stress at one level of organization may also have an impact on another level. Since it is difficult to detect the effects of anthropogenic stress at the individual organismic level, they are more often investigated at a population or community level (Jenouvrier et al., 2003). The present study is designed to assess the effect of organic carbon on benthic fauna in the estuary and coastal area. The main objective of this study is to describe the spatial and temporal changes in the diversity and abundance of macro benthic fauna in relation to environmental variables at estuary and coastal area of Puducherry, Tamil Nadu coast.

\section{Materials and Methods}

\section{Study area}

The Puducherry were located (latitude $11^{0}$ $54^{\prime} 2 \mathrm{~N}$ and longitude $79^{\circ} 49^{\prime} 45 \mathrm{E}$ ) on the Tamil Nadu, Southeast Coast of India (Fig. 1). Puducherry coastal area is polluted due to the discharge of industrial, domestic and agricultural wastes through small tributaries and channels in to the coastal waters. There are several major and small industries are 
located nearer to the study area, discharging their effluents continuously into the estuary and coastal waters.

\section{Sampling and analysis}

Sediment samples were collected for the period of one year (January, 2014 to December, 2014) covering all the four seasons (post monsoon, summer, pre monsoon and monsoon). Three replicate samples were collected using a long armed Van- Veen grab $\left(0.1 \mathrm{~m}^{2}\right)$ at each station. After collection, the samples were transferred into plastic trays. The larger organisms were handpicked and then the sediment samples were sieved through $0.5 \mathrm{~mm}$ mesh screen in order to pick up the macro benthic animals and subsequently the samples were preserved in 5\% formalin. The organisms were stained with rose Bengal solution for enhanced visibility during identification. All the specimens were assorted enumerated and identified (Fauvel, 1953; Day, 1967; Barnes, 1980; Lyla et al., 1999). About $100 \mathrm{gm}$ of dried sediment was sieved by mechanical shaker (Buchanan, 1984) to investigate the sediment composition. The sand fraction was determined as the amount of sediment retained by sieve of $125 \mathrm{~mm}$ size. The portion which passes through the sieve of $125 \mathrm{~mm}$ but retained by sieve of $0.063 \mathrm{~mm}$ is slit and the fraction which passes through the sieve of $0.063 \mathrm{~mm}$ is clay. The surface sediment was separated (upper $2 \mathrm{~cm}$ ) from the grab for the analysis of Total Organic Carbon content.

Total Organic Carbon content (TOC) was estimated using chromic acid oxidation method followed by titration with ammonium ferrous sulphate (Walkley Black method) as modified by (Gaudette $e t$ al., 1974).

\section{Statistical tools}

Macrofauna reflect the ecological and environmental status. They were assessed in terms of the number of individuals or specimens $(\mathrm{N})$, number of species $(\mathrm{S})$, total abundance (A), Margalef species richness (d), Pielou's eveness (J'), and Shannon index ( $\left.H^{\prime}\right)$ at each site. The data analyses were made using the statistical software PRIMER ver. 6.0 (Clarke and Gorley, 2006).

\section{Results and Discussion}

\section{Physico- chemical Parameters}

Among the study area, significant changes in the temporal and spatial variation of Physico- chemical parameters were discerned (Fig. 2, 3, 4 \& 5). In Puducherry, the temperature level varied from $26.2{ }^{0} \mathrm{C}$ to $33.7{ }^{0} \mathrm{C}(29.4 \pm 1.66)$ with minimum value during Monsoon at station PDY III and maximum value during summer at station PDY-I; the salinity ranged from 28.6 psu to $35.2 \mathrm{psu}(32.32 \pm 1.03)$ with maximum value recorded form summer at station PDY $I$ and minimum value during monsoon at station PDY-VI; the $\mathrm{pH}$ level varied from 7.73 to $8.40(8.15 \pm 0.05)$ with minimum value from Post monsoon at station PDY-I and maximum value recorded from summer at station VI; the dissolved oxygen level fluctuated from $1.12 \mathrm{mg} / \mathrm{l}$ to $6.76 \mathrm{mg} / \mathrm{l}$ (4.51 \pm 0.54 ) with maximum during Monsoon at station PDY-III and minimum value from Summer at station PDY-II,Fig.1, 2, 3 and 4) respectively. The negative significant value $\mathrm{r}=-0.613 ; \mathrm{p}<0.05$ in station PDY-II.

\section{Sediment texture}

Sediment texture analyses indicated a diverse nature of substratum along the entire sampled area. The maximum value of sand 
(94.21\%) was noticed at (PDY-III). The minimum of $1.91 \%$ was measured in the estuary region (PDY-II). The higher value of silt $(43.90 \%)$ was noticed at coastal (PDYVI). The lower of $5.01 \%$ was measured in the mouth region (PDY-III) and the highest value of clay $(81.58 \%)$ was observed in the estuary (PDY-II) and the low value of $0.74 \%$ was measured mouth region (PDYIII) shown in the Fig. 6.

\section{Total Organic carbon}

The total organic carbon varied from 13.26 to $0.75 \mathrm{mgC} / \mathrm{g}(2.63 \pm 0.50)$ with maximum value recorded from summer at station PDY-II and minimum value observed for monsoon at station PDY III, positive significant TOC and Clay $(\mathrm{r}=0.898 ; \mathrm{p}>$ 0.01) shown in Fig. 7.

\section{Macro benthic composition}

The percentage composition of benthic macro fauna from Puducherry, polychaetes were founded to be dominant group by constituting $60 \%$ of the total benthic organisms recorded. Second dominant group with percentage of Bivalves $11 \%$ and Amphipods, Gastropods and Isopods came in next in order with contributions of $11 \%$, $11 \%$ and $6 \%$ respectively. Decapod contributed with a meager distribution of 1 $\%$ Fig 8.

\section{Diversity distribution}

A table 1 showed seasonal mean value of total benthic fauna in six stations from Puducherry region. A total of 94 species of macrobenthic organisms belonging three major phyla namely Annelida, Crustacean and Molluscs species were recorded. Species belonging to genus polychaetes were Capitella, Cossura, Drilonereis, Nephtys, Nereis and Prionospio Bivalves Meretrix gastropods Oliva, Amphipods, Ampithoe and Caprella and Isopods Janaira was recorded at Puducherry stations. The maximum number of species recorded in station PDY-VI from coastal region and minimum number of species recorded in station PDY-III from estuary area. A total of 10 macrobenthic species were dominant occurred in Puducherry study area. They were restricted to the namely Armandia longiculata Boccardia polybranchia Cirratulus concinnus Eulalia bilineata Eulalia macroceros Exogone clavator Leanira hystricis Loandalai capensis Spionidae sp Terebellidae sp Bivalves Donax Veligers Meretrix Meretrix Gastropods Littorina varigatus Nassarius variegates Natica sp. Turris Indica Amphipods Gammaropsis sp Grandidierella sp Harpinia laevis Isopods Mirocerberus sp. Plurocope dasyure however of the no recorded in Puducherry study area. The Puducherry study area most dominant genus polychaetes Capitella ,Cossura ,Euclymene, Glycinde Nephtys Nereis Pisionidens and Prionospio Bivalves Meretrix Gastropods Littorina and Turritella Amphipods Ampithoe and Ingolfiella Isopods Anthura Paragnathia and Decopod Emerita. A totally 35 species were dominantly occurred in Puducherry station there was consistently 9 species were dispersed in both study area they were constituted by Polychaetes Capitella capitata, Cossura coasta, Nephtys dibranchis, Nereis capensis, Prionospio capensis and Prionospio pinnata flowed by gastropods Bullia vitata and Turritella attenuate and amphipodos Caprella mendax most commonly were Occurred in both study area (Table 1).

Seasonal average of species abundance in station wise among the macrobenthic fauna polychaetes, bivalve, gastropods, amphipods, iosopods and decopoda were recorded in all station shown the Fig10. It 
was observed that along the Puducherry coast except for PDY VI, rest of the regions showed dominance of macrobenthic polychaetes. Polychaetes groups dominated the macrobenthic population and absence of Decapod species Emerita asiatica at PDY I and PDY- II (Fig. 9).

\section{Macro benthic density}

A significant variation $(\mathrm{p}<0.009$; Two-way ANOVA) in the abundance of polychaetes was observed in different stations. The population density of benthic organisms estimated in different study area at Puducherry is shown in Fig. 10. In Puducherry, the density varied from 450 to 2250 Nos $/ \mathrm{m}^{2}$ with minimum density recorded from station PDY III during summer season 2014 and maximum in station PDY VI.

\section{Diversity Index}

The species diversity of polychaete was estimated based on Shannon - Wiener index. Along the Puducherry, species diversity ranged from 3.735 to 5.266 with minimum value in station PDY-III during monsoon season 2014 and maximum value observed in station PDY-VI during summer season 2014. The species richness varied between 4.405 to 8.889 with higher value in station PDY-VI during summer season 2014 and lower value in station PDY-III during post monsoon season 2014. The species evenness (pielou's evenness) fluctuated between 0.953 to 0.983 with maximum value recorded in station PDY-VI during summer season 2014 and minimum in station PDY-I during pre monsoon season 2014 (Fig. 11).

\section{Dominant plot}

In present study, the data pertaining to species diversity were also used for $\mathrm{k}$ - dominance plot in station of Puducherry to organic polluted and sediment nature of study area. As an oddity the k- dominance drawn for the station of puducherry study area shown that the diversity curve of both station were founded to lie above the abundance curve indicating the pristine organic load and sediment nature of Estuary compare to coastal system by the fact that the dominance of $\mathrm{k}$ - strategists or conservative species. Station PDY I \& II were indicated to lower diversity compared station PDY III, IV, V \& VI (Fig. 12).

\section{Correlation matrix}

The correlation was done between the benthic diversity index and sediment properties and physical parameter Puducherry water. The resulting matrix revealed that, they DO had very strong negative correlation with TOC and Diversity, richness and evenness positive correlation with, water salinity, $\mathrm{pH}$ and DO. The Diversity, richness and evenness had positive correlation with silt and negative with sand and TOC (Table 2).

\section{Cluster analysis}

The Puducherry study area the result of Bray-curtis similarity index showed (Fig. 13) two groups were formed in Puducherry station. The first group $83 \%$ of Similarity between PDY-VI and PDY-V compared between two groups.

In this paper discuss with compared study of environmental parameter and macrobenthic diversity from Puducherry. Temperature is an important ecological factor, which influence distribution of benthic organisms. The temperature showed marked between Puducherry study areas the maximum recorded in station PDY-I in summer season is might be due to heavy downpour, which 
caused drastic fluctuations in the sampling stations. Positive relationship between the abundance of benthic fauna and concentration of organic carbon in sediments had been documented by many workers (Parulekar et al., 1975 and Damodaran, 1973). The salinity is low level positive correlation obtained between salinity and temperature because high level freshwater due this station. The low $\mathrm{pH}$ observed during monsoon from station PDY-I and attributable to factors such as the removal of $\mathrm{CO}_{2}$ by photosynthesis through bicarbonate degradation, the dilution of seawater by the fresh water influx (Satheeshkumar et al., 2011). The high pH values recorded during summer in station PDY-V might be due to the influence of sweater penetration and high biology activity (Saravanakumar et al., 2008). The strongly significant negative correlation between DO and total organic carbon recorded during summer season in station PDY II it was located sewage channel are joining point; because this station more sewage and industrial wastewater discharge, so highly rich organic matter mixing sediment, high organic production sinking and decomposing of large amount of TOC as for the oxygen decreased (Wu et al., 2009).

Distribution of benthic organisms, species diversity, species evenness, and species richness were closely accompanied by changes in the physical and chemical characters of the water resulting from anthropogenic effect on the ecosystem (Kailasam 2004). The present study indicates higher polychaete diversity as compared to the earlier reports (Amar et al., 2011). It was noticed that puducherry coast of India is rich in macrobenthos in terms of total abundance and diversity; this was clear from table 1. Stations PDY-V and PDY-VI located from coastal area and with the silt and clay percentage is high, has a community high species diversity, species richness and individual numbers than the station PDY-II and PDY-III. The communities are comprised of variety of larger but less abundant individual organisms which are associated with unpolluted sediment (Ruiz et al., 2005). In Puducherry study area, station PDY-III species richness, diversity and individual abundance are all very low, because the station PDY-III was located mouth area this area dragging so sediment nature is distributed. But PDY-I and PDY-II was high organic pollution and clay percentage is high and TOC level was high so, species richness, diversity and individual abundance are low, but some organisms found are dominated by polychaetes of the Capitella capitata, Cossura coasta, Nephtys dibranchis and Nereis capensis, specie symptomatic of high organic pollution and low dissolved oxygen tolerated in this environment area (Pearson and Rosenberg, 1978; Ismail, 1992). Sediment characteristics have long been recognized as a determining factor directly controlling the presence and abundances of the soft bottom fauna (Gray, 1981). (Hily, 1987) said that each species tolerates a specific sediment particle size range. The central part of this gradient corresponds to the optimal conditions for the species in terms of abundances; individual numbers may be in this for absence of species presence.

k- Dominance plot clearly demonstrated the polluted nature of the puducherry study area diversity curve of PDY-I and PDY-III was above than other station. So it is indicate high polluted nature of study area. The similar to this, study done elsewhere on the effected of industrial and sewage outfalls on tropical macrobenthic community also clearly elucidated the pollution nature of station by showing the diversity curve (Bigot et al., 2006). 
Table.1 Species check list in overall mean value of season

\begin{tabular}{|c|c|c|c|c|c|c|}
\hline Species & PDY I & PDY II & PDY III & PDY IV & PDY V & PDY VI \\
\hline \multicolumn{7}{|l|}{ Polyaetes } \\
\hline Ancistrosyllis parva & - & 1 & - & 4 & 1 & 5 \\
\hline Arabella mutans & - & 2 & - & - & 4 & - \\
\hline Armandia intermedia & 2 & 2 & - & 3 & 4 & 5 \\
\hline Armandia longiculata & - & - & - & - & - & - \\
\hline Boccardia polybranchia & - & - & - & - & - & - \\
\hline Capitella capitata & 11 & 6 & - & 8 & 11 & 14 \\
\hline Cerapus crassicornis & - & 2 & - & 4 & 3 & 1 \\
\hline Cirratulus africanus & 2 & - & 3 & - & 4 & 7 \\
\hline Cirratulus chrysoderma & - & 2 & 2 & 2 & 2 & 4 \\
\hline Cirratulus concinnus & - & - & - & - & - & - \\
\hline Cirratulus filiformis & 5 & - & 2 & - & 1 & 3 \\
\hline Cossura coasta & 10 & 4 & - & 4 & 6 & 8 \\
\hline Dorvilla gardineri & - & 2 & 2 & 2 & 3 & 4 \\
\hline Drilonereis flacata & - & - & - & 1 & - & 2 \\
\hline Drilonereis monroi & - & 2 & - & 3 & - & 1 \\
\hline Epidiopatra gilchristi & - & - & 1 & - & 2 & - \\
\hline Euclymene annandalei & 4 & 2 & 1 & - & 2 & 9 \\
\hline Eulalia bilineata & - & - & - & - & - & - \\
\hline Eulalia macroceros & - & - & - & - & - & - \\
\hline Eunice indica & 3 & 4 & - & - & 5 & 3 \\
\hline Exogone clavator & - & - & - & - & - & - \\
\hline Glycinde capensis & 2 & 3 & 5 & 4 & 1 & 4 \\
\hline Goniada emeriti & - & - & - & - & - & - \\
\hline Goniadides falcigera & 2 & - & 2 & 2 & 5 & - \\
\hline Leanira hystricis & - & - & - & - & - & - \\
\hline Loandalai capensis & - & - & - & - & - & - \\
\hline Lopadorhynchus nationalis & - & 3 & - & 3 & 5 & 5 \\
\hline Lumbrineris aberrans & 3 & 5 & - & 2 & 4 & 1 \\
\hline Lumbrineris heteropoda & - & - & - & 2 & - & - \\
\hline Nephtys dibranchis & 11 & 4 & 5 & 5 & 8 & 12 \\
\hline Nereis capensis & 7 & 3 & 2 & 5 & 3 & 7 \\
\hline Notocirrus australis & 1 & - & 3 & 1 & 6 & 1 \\
\hline Notomastus aberans & 2 & 2 & 2 & 3 & 2 & 4 \\
\hline Onuphis geoformis & 3 & 2 & - & - & 1 & 5 \\
\hline Owenia fusiformis & - & 2 & 1 & - & 2 & - \\
\hline Pisione Africana & 5 & - & 4 & 2 & - & - \\
\hline Pisionidens indica & - & 3 & 1 & 4 & 10 & 9 \\
\hline Plurocope dasyure & 2 & 2 & 1 & - & 2 & 3 \\
\hline
\end{tabular}




\begin{tabular}{|c|c|c|c|c|c|c|}
\hline Polydora ciliata & - & 3 & 1 & 3 & - & - \\
\hline Prionospio capensis & 3 & - & 3 & 2 & 6 & 7 \\
\hline Prionospio cirrifera & 1 & - & 1 & 2 & - & 3 \\
\hline Prionospio pinnata & 6 & 2 & - & 3 & 5 & 7 \\
\hline Prionospio sexoculata & 1 & - & - & - & 4 & 5 \\
\hline Scoloplella capensis & - & - & - & 3 & 1 & 1 \\
\hline Sphaeroma serratum & 1 & 3 & 2 & - & - & 3 \\
\hline Spionidae sp & - & - & - & - & 1 & 1 \\
\hline Sternaspis scutata & - & 2 & - & - & 1 & 2 \\
\hline Syllidia armata & 1 & - & - & 2 & - & 2 \\
\hline Syllis longocirrata & - & - & - & 2 & 1 & 2 \\
\hline Terebellidae sp & - & - & - & - & - & - \\
\hline Terribellides streemi & - & - & - & 1 & 8 & 2 \\
\hline \multicolumn{7}{|l|}{ Bivalves } \\
\hline Anadara granosa & 2 & 2 & - & 1 & 2 & 3 \\
\hline Anadara veligers & 2 & 1 & 3 & 5 & 5 & 1 \\
\hline Cardium setosum & 1 & 4 & 1 & 2 & - & 4 \\
\hline Cardium veligers & 3 & 1 & 2 & 3 & 2 & 3 \\
\hline Donax Veligers & - & - & - & - & - & - \\
\hline Donax cuneatus & 3 & 3 & - & - & 3 & 6 \\
\hline Donax Scortum & - & - & - & 3 & - & - \\
\hline Meretrix casta & 4 & 2 & 2 & 1 & 5 & 6 \\
\hline Meretrix Meretrix & - & - & - & - & - & - \\
\hline Meretrix veligers & 7 & 2 & 2 & 4 & 2 & 4 \\
\hline Paphia textile & - & 4 & 2 & 3 & 5 & 5 \\
\hline \multicolumn{7}{|l|}{ Gastropods } \\
\hline Bullia vitata & 2 & 2 & 2 & 2 & 4 & 5 \\
\hline Littorina scarba & 5 & 2 & 4 & 4 & 2 & 6 \\
\hline Littorina varigatus & - & - & - & - & - & - \\
\hline Nassarius variegatus & - & - & - & - & - & - \\
\hline Nassarius veligers & 5 & 2 & - & 4 & 4 & 1 \\
\hline Natica sp. & - & - & - & - & - & - \\
\hline Natica veligers & 1 & - & 2 & 4 & 4 & 5 \\
\hline Oliva nebulosa & 4 & 3 & - & 2 & 1 & 2 \\
\hline Turris Indica & - & - & - & - & - & - \\
\hline Turris veligers & 1 & 2 & - & - & - & 2 \\
\hline Turritella attenuata & 5 & 4 & 3 & 3 & 6 & 6 \\
\hline Xancus veligers & 1 & 2 & 1 & 2 & 3 & 4 \\
\hline
\end{tabular}




\begin{tabular}{|l|c|c|c|c|c|c|}
\hline Amohipods & & & & & & \\
\hline Ampithoe romondi & 2 & 3 & 2 & 5 & 3 & 7 \\
\hline Ampithoe rubricata & 2 & 2 & 2 & 1 & 4 & 3 \\
\hline Caprella mendax & 5 & 2 & 2 & 3 & 2 & 3 \\
\hline Gammaropsis sp & - & - & - & - & - & - \\
\hline Grandidierella sp & - & - & - & - & - & - \\
\hline Harnellia incerta & - & 3 & 2 & 3 & 2 & - \\
\hline Harpinia laevis & - & - & - & - & - & - \\
\hline Ingolfiella putealis & 6 & - & 2 & 2 & 4 & 6 \\
\hline Microprotopus maculatus & - & - & - & - & - & - \\
\hline Phaxocephalus holbolli & 1 & 3 & 3 & 3 & - & 2 \\
\hline Urothoe sp. & 4 & - & 2 & 2 & 3 & 5 \\
\hline & & & & & & \\
\hline Isopods & & & & & & \\
\hline Angeliera phreaticola & 2 & - & 2 & 1 & 2 & 1 \\
\hline Anthura gracilis & 2 & 2 & - & 4 & 3 & 7 \\
\hline Calabozoa pellucida & 4 & 3 & 2 & 2 & 2 & 1 \\
\hline Jaeropsis beuroisi & 1 & - & 2 & 2 & 3 & 6 \\
\hline Janaira gracilis & - & 2 & - & - & - & - \\
\hline Mirocerberus sp. & - & - & - & - & - & - \\
\hline Paragnathia formica & 3 & 2 & 2 & 3 & 6 & 3 \\
\hline Plurocope dasyura & - & - & - & - & - & - \\
\hline & & & & & & \\
\hline Decapod & & & & & & \\
\hline Emerita asiatica & - & - & 9 & 2 & 4 & 5 \\
\hline Total & 166 & 126 & 100 & 158 & 210 & 264 \\
\hline & & & & & \\
\hline & & - & & & & \\
\hline
\end{tabular}

Table.2 Correlation matrix on physic-chemical and benthic diversity

\begin{tabular}{|c|c|c|c|c|c|c|c|c|c|c|c|}
\hline Parameter & Tempe & Salinity & $\mathrm{pH}$ & DO & TOC & Sand & Silt & Clay & Diversity'H & Richness'd & Evenness'J \\
\hline Tempe & 1 & & & & & & & & & & \\
\hline Salinity & 0.649 & 1 & & & & & & & & & \\
\hline $\mathrm{pH}$ & -0.088 & $0.974 * *$ & 1 & & & & & & & & \\
\hline DO & 0.038 & 0.548 & 0.542 & 1 & & & & & & & \\
\hline TOC & $0.975 * *$ & -0.086 & -0.221 & -0.631 & 1 & & & & & & \\
\hline Sand & $-0.877 *$ & 0.054 & 0.217 & 0.31 & $-0.938^{* *}$ & 1 & & & & & \\
\hline Silt & $0.684 *$ & 0.441 & 0.299 & -0.065 & $0.696^{*}$ & $-0.832^{*}$ & 1 & & & & \\
\hline Clay & 0.81 & -0.461 & -0.601 & -0.438 & $0.898^{*}$ & $-0.879 *$ & 0.466 & 1 & & & \\
\hline Diversity'H & 0.167 & $0.805^{* *}$ & $0.742 *$ & 0.067 & -0.147 & -0.327 & $0.78 *$ & $-0.147 *$ & 1 & & \\
\hline Richness'd & 0.236 & $.864 *$ & $0.756^{*}$ & 0.191 & -0.18 & -0.332 & $0.74^{*}$ & -0.202 & $0.942 * *$ & 1 & \\
\hline Evenness'J & -0.261 & 0.56 & $0.677^{*}$ & 0.05 & -0.265 & 0.184 & 0.281 & -0.139 & 0.667 & 0.427 & 1 \\
\hline
\end{tabular}

**. Correlation is significant at the 0.01 level (2-tailed).

*. Correlation is significant at the 0.05 level (2-tailed). 
Fig.1 The Puducherry study area with locations of sample stations labeled PDY I, II and III the location of estuary and PDY IV, V and VI coastal area respectively

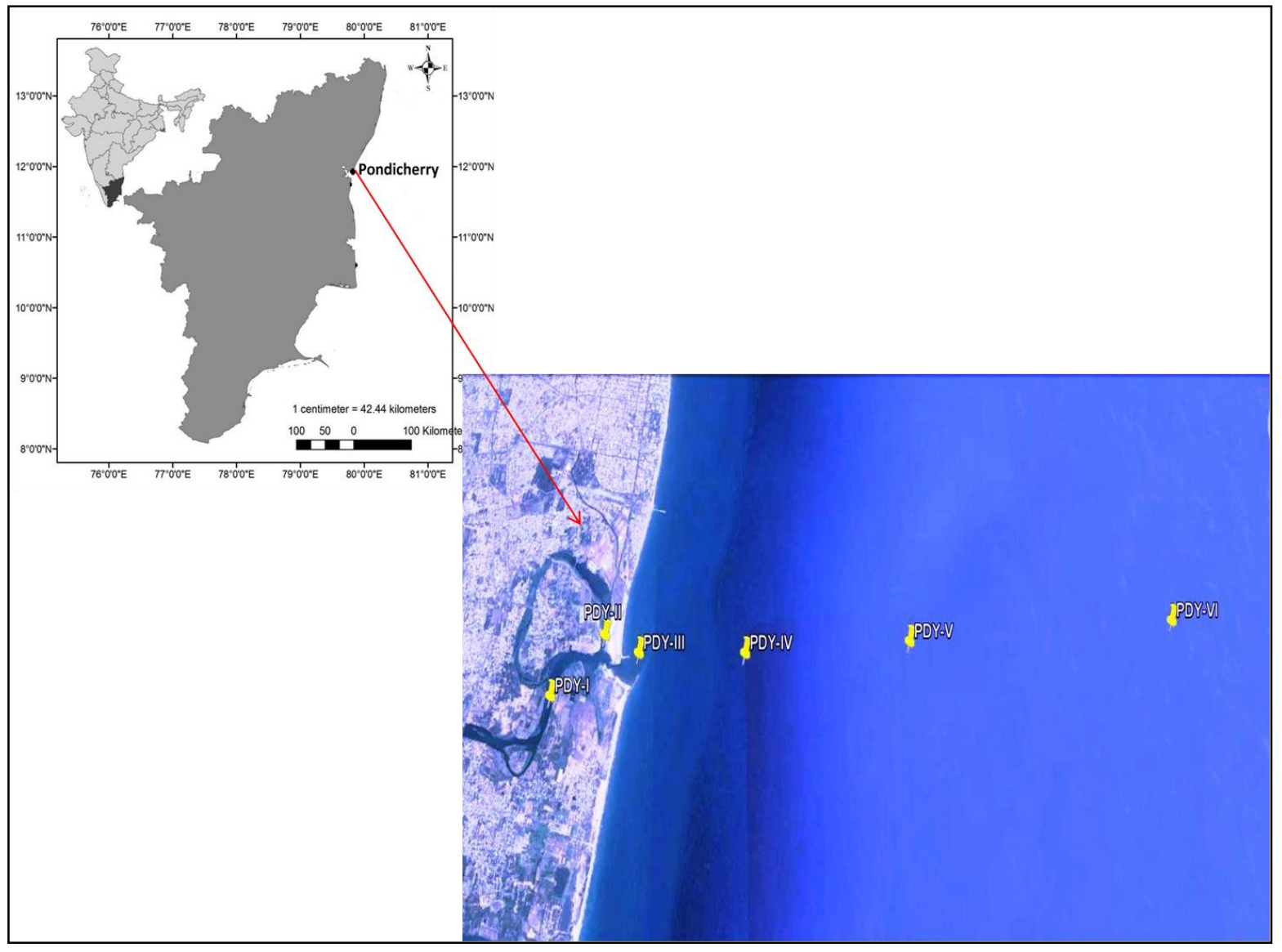

Fig.2 Seasonal variation of Temperature from Puducherry station.

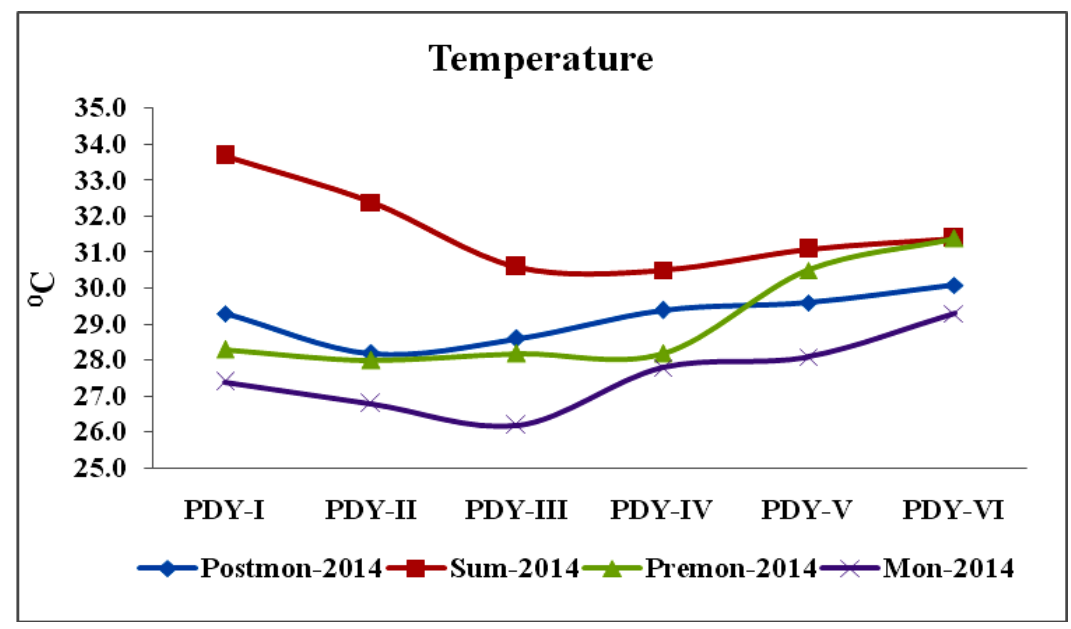


Fig.3 Seasonal variation of Salinity from Puducherry station

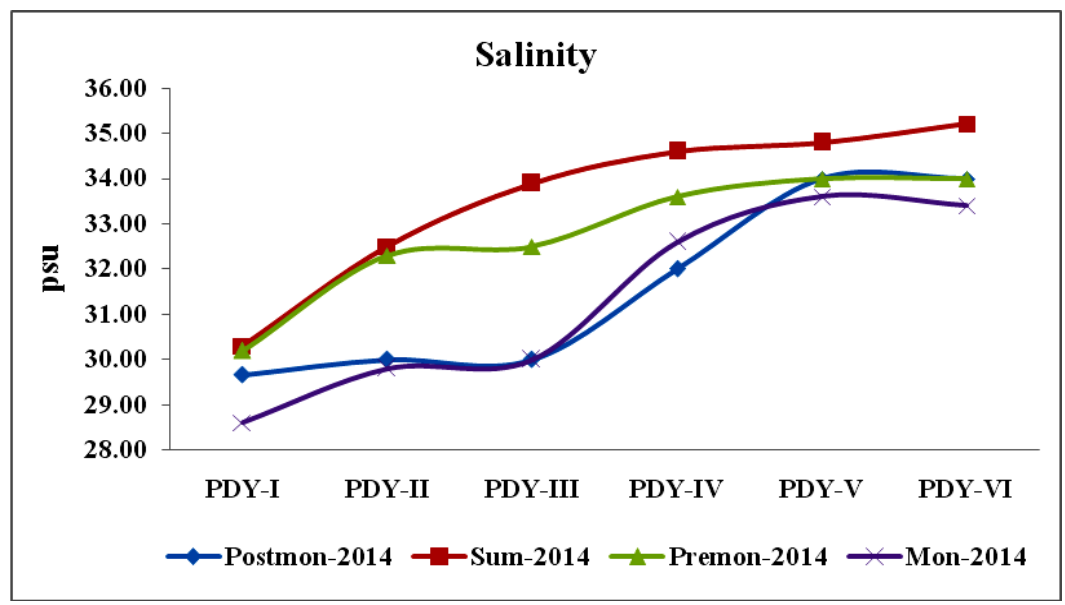

Fig.4 Seasonal variation of $\mathrm{pH}$ from Puducherry station

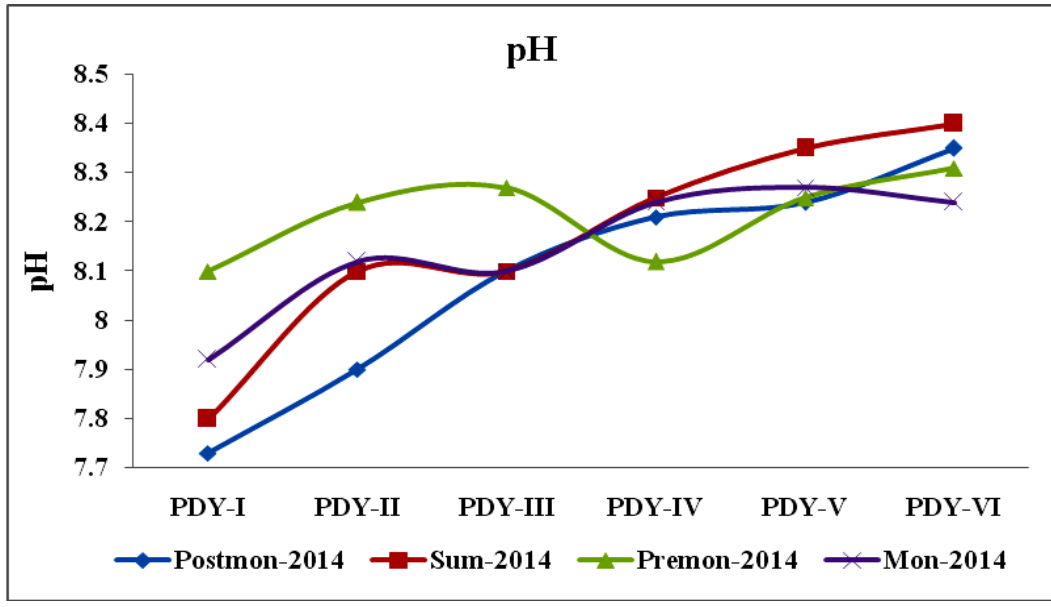

Fig.5 Seasonal variation of Dssolved oxygen from Puducherry station

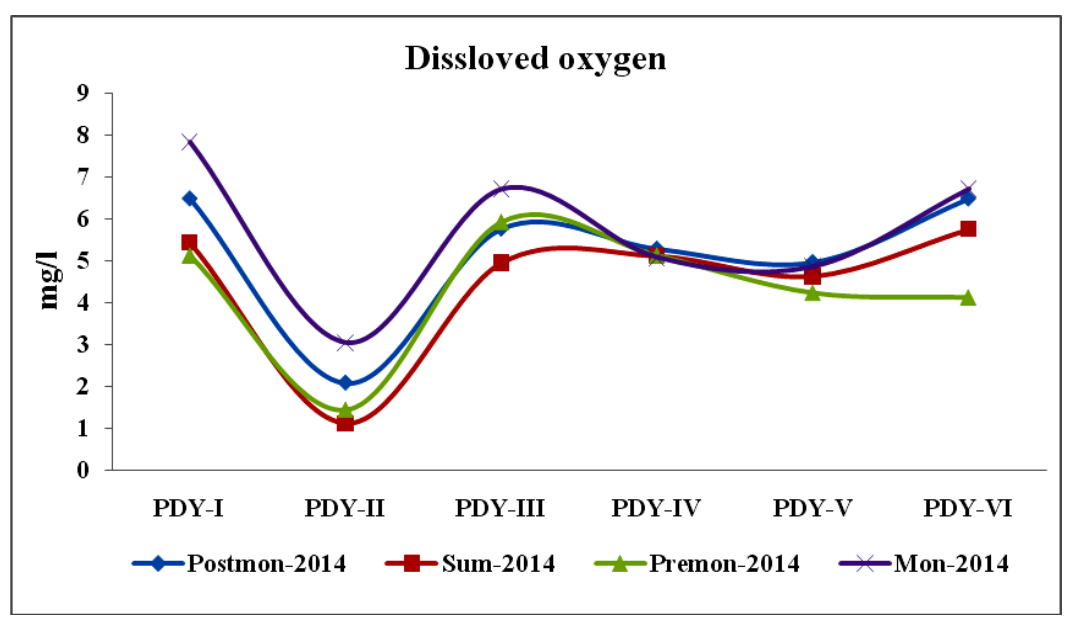


Fig.6 The percentage of sediment texture from Puducherry study area

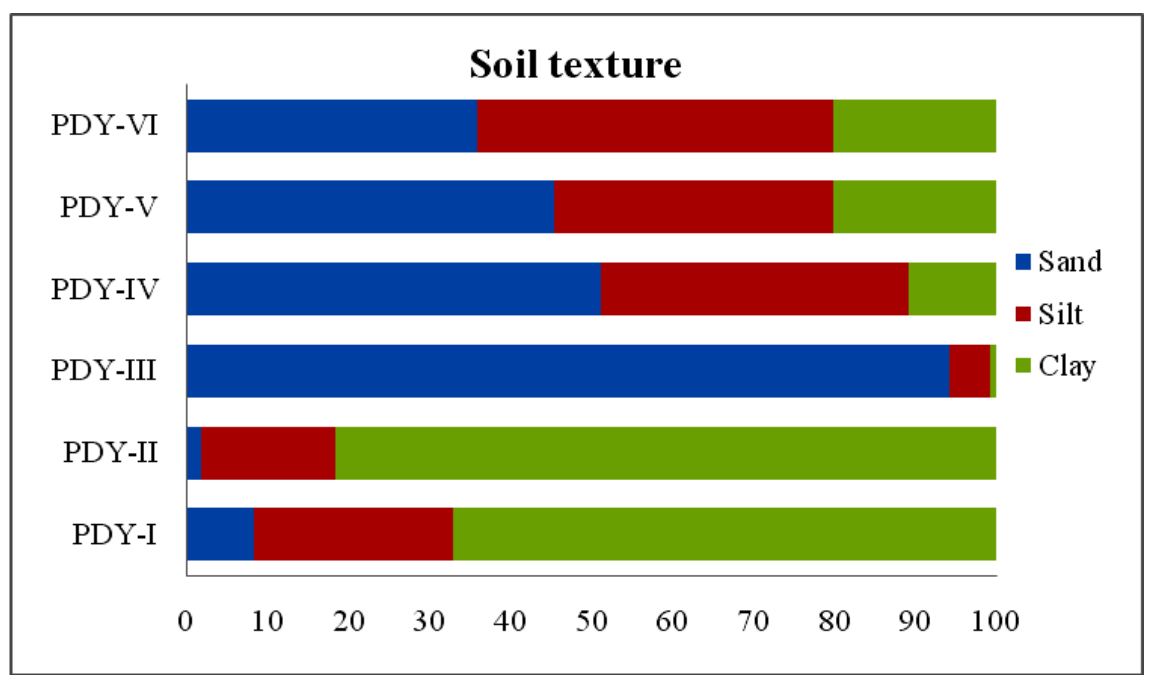

Fig.7 Seasonal variation of Total organic carbon from Puducherry station

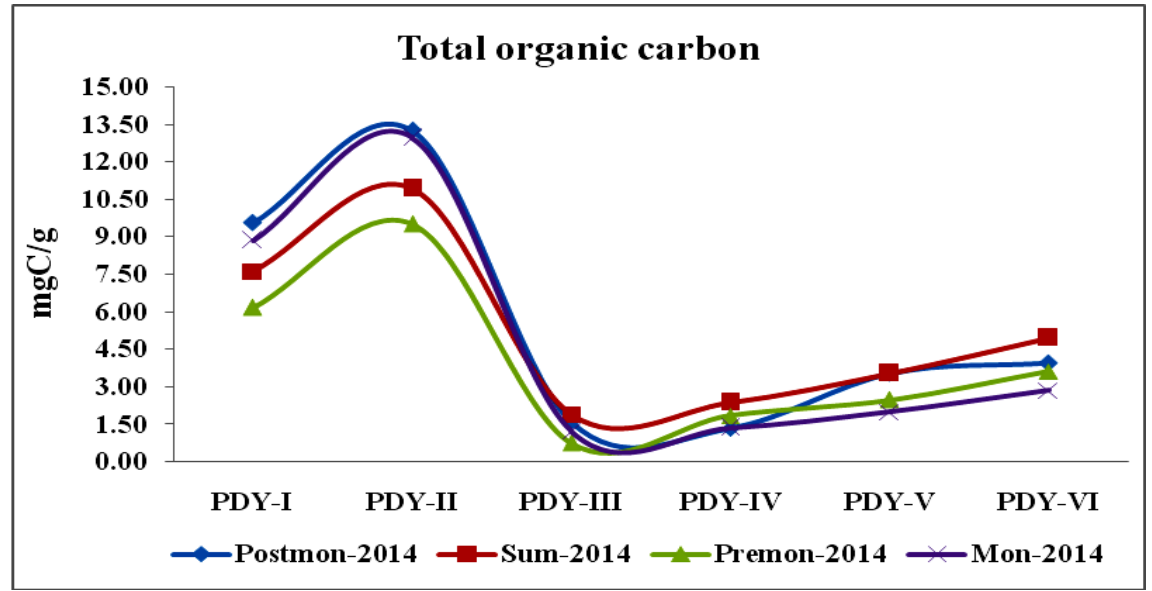

Fig.8 Percentage composition of macrobenthic fauna from Puducherry station

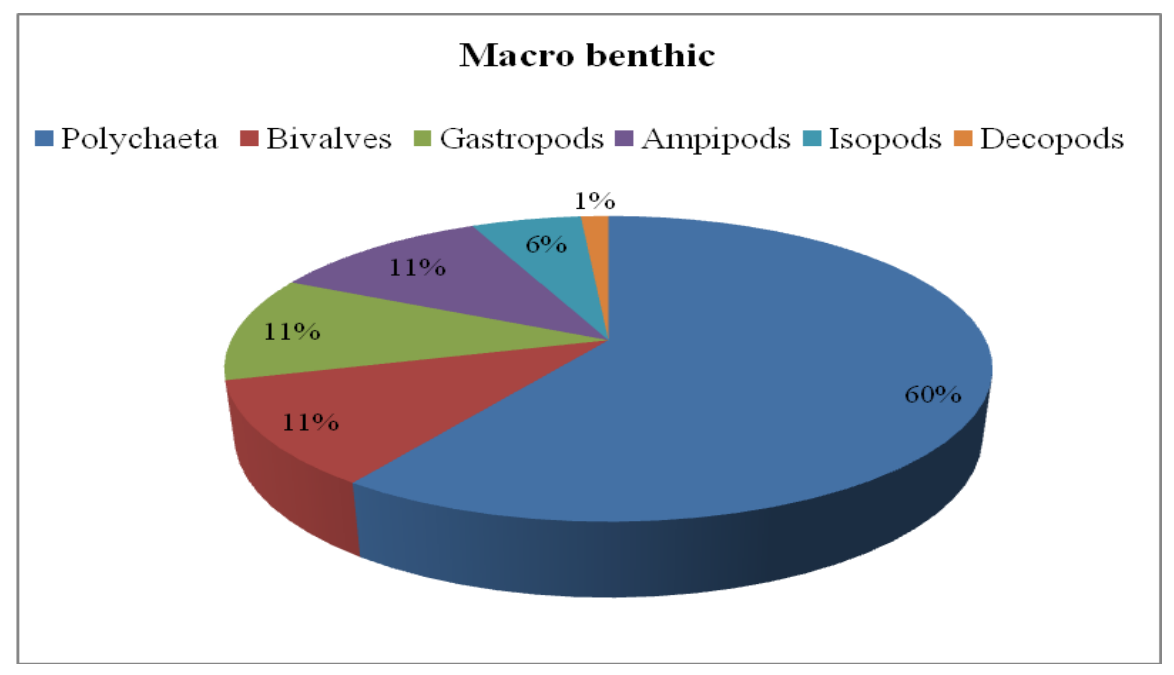


Fig.9 Overall overage of abundance of macrobenthic fauna in Puducherry station

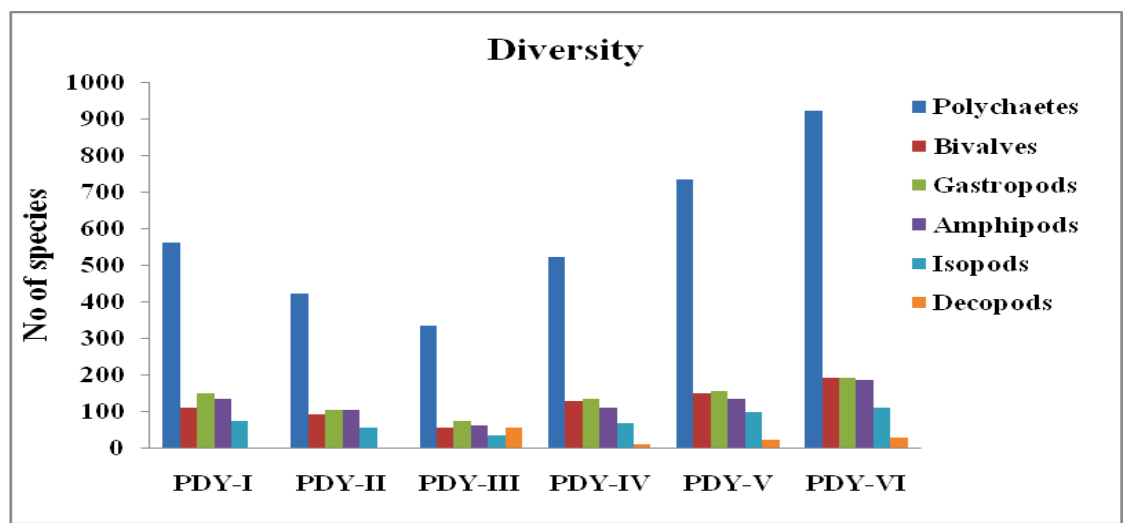

Fig.10 Seasonal variation of macrobenthic density in Puducherry station

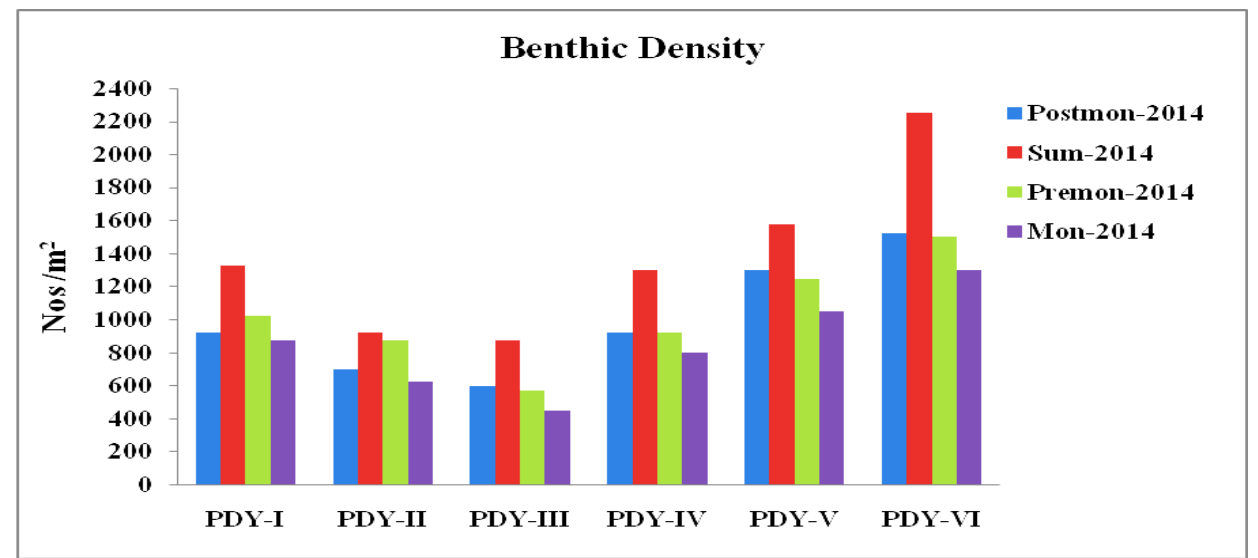

Fig.11 Diversity indices of Puducherry station
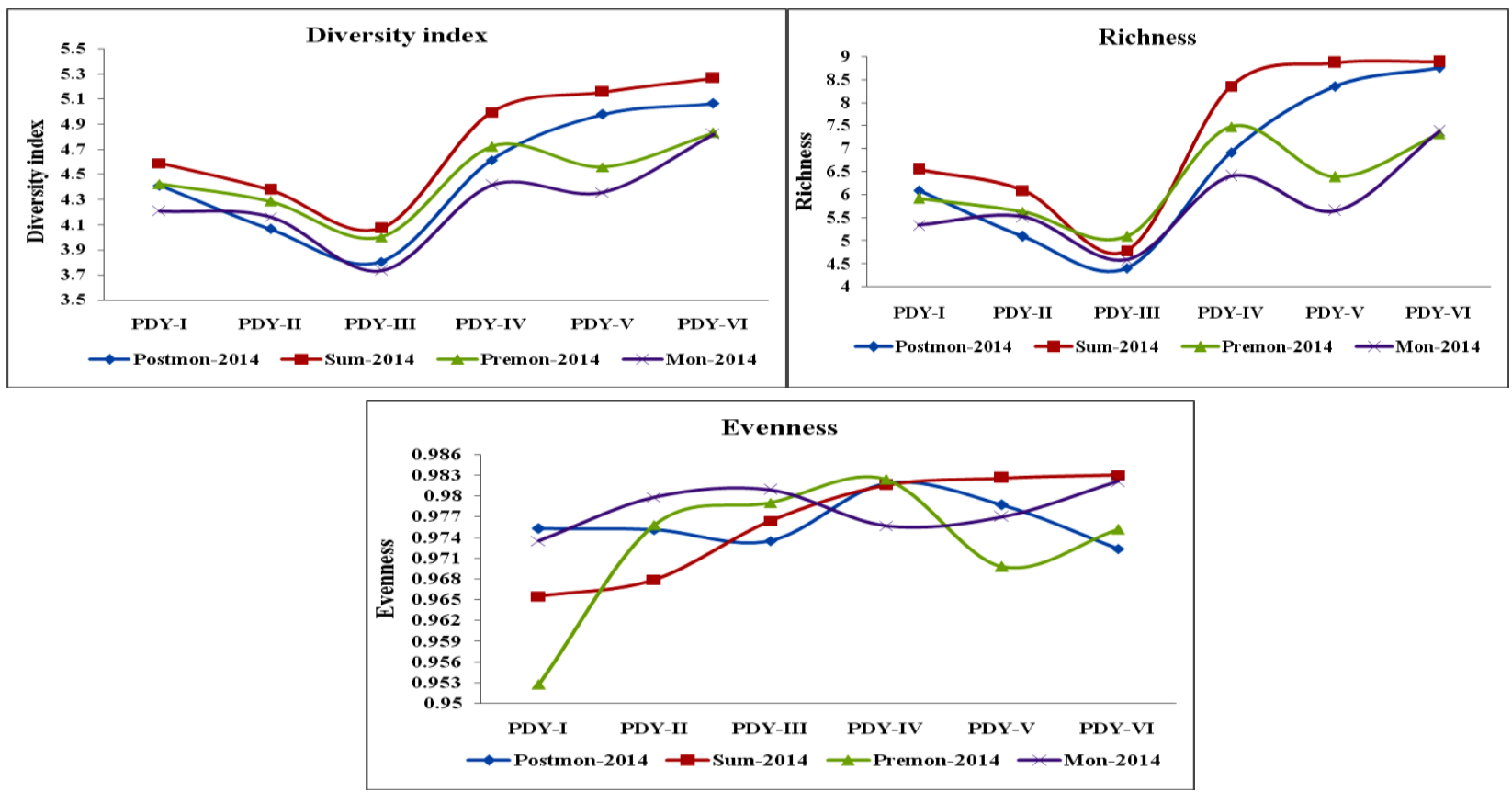
Fig.12 ABC plats for species abundance data in Puducherry station.

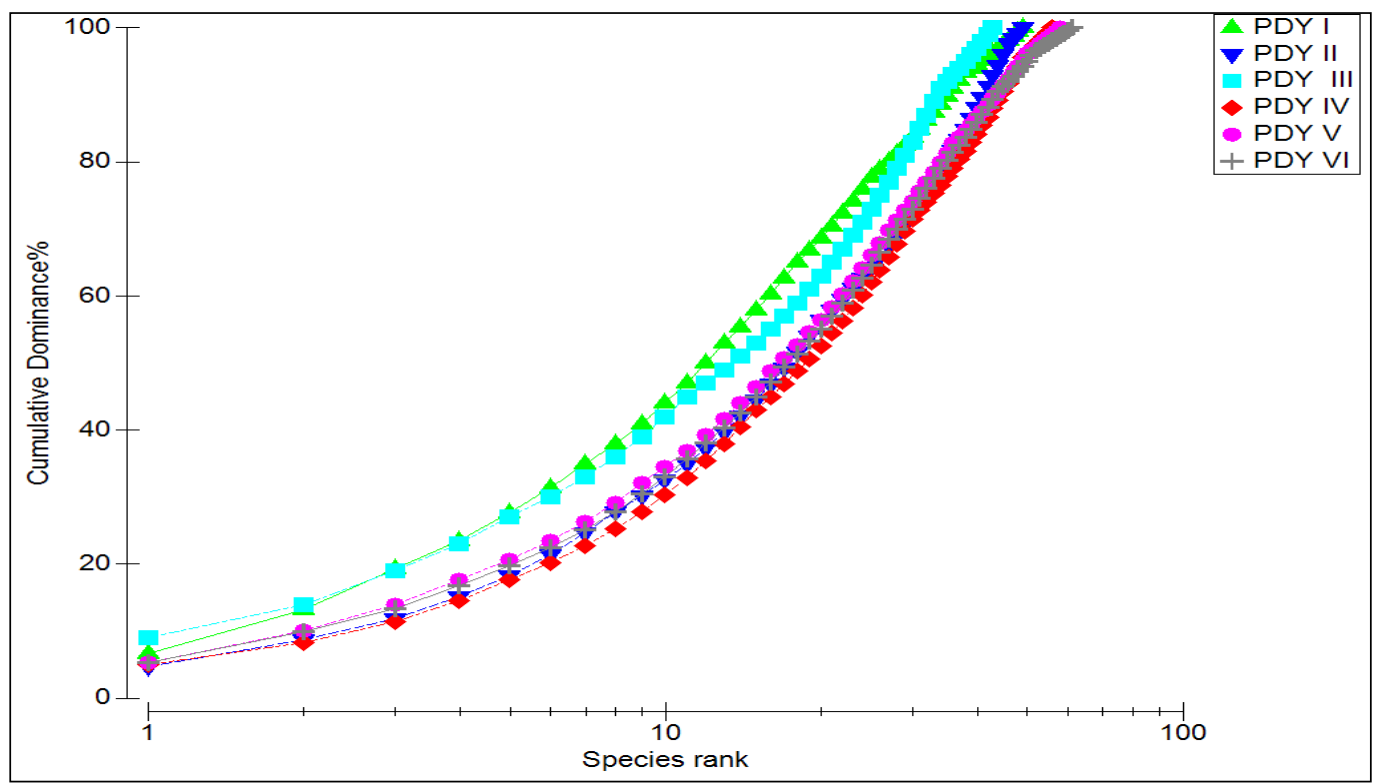

Fig.13 cluster explain with similarity between Puducherry Station

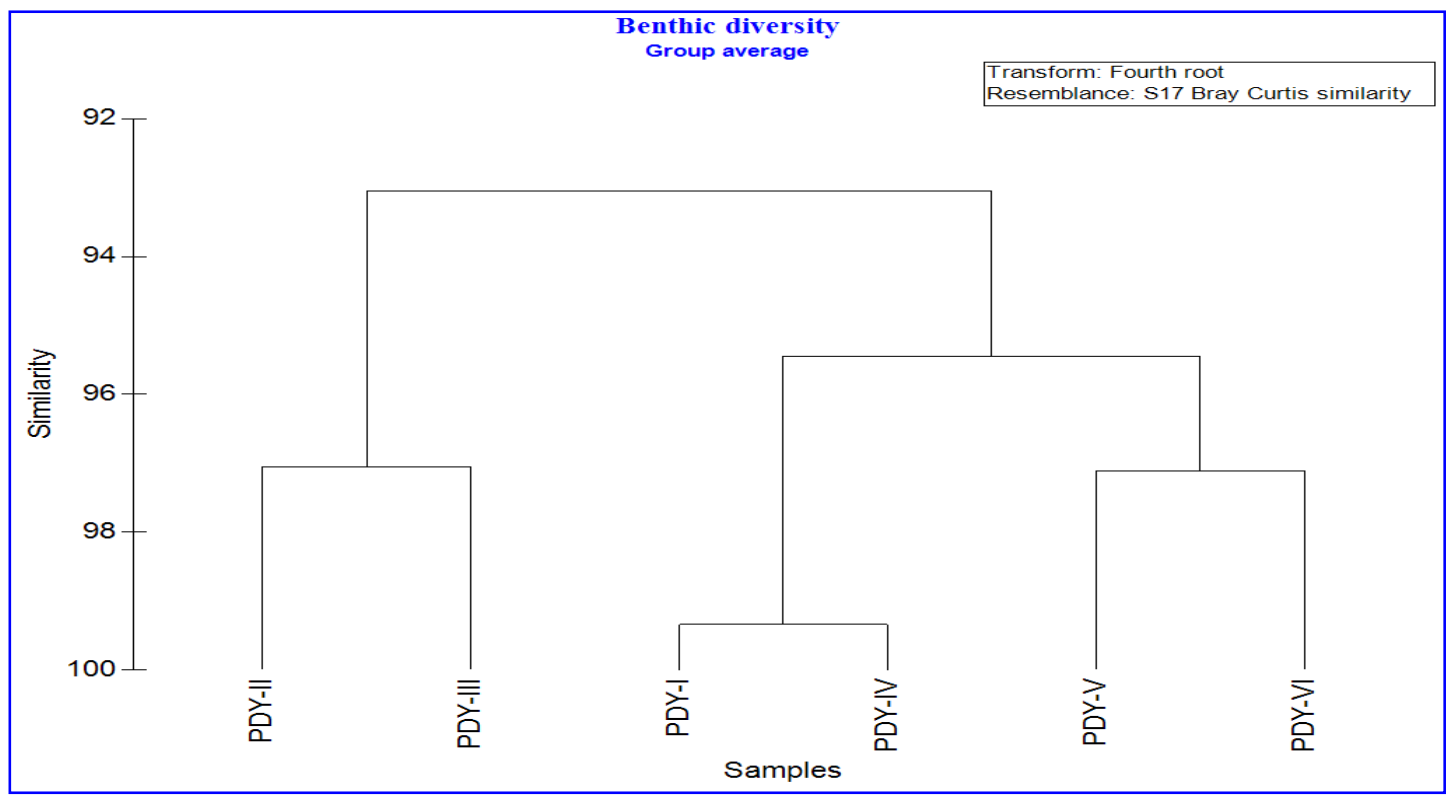

The cluster and correlation analysis compared Puducherry station, overall similarity $43 \%$ between stations PDY V and PDY-VI is closely similarity shown in Fig. 13. These studies are slightly unpolluted area because TOC and sediment texture is favorable for abundance of species. The results of this baseline macrofauna survey therefore display signs that sections of Puducherry, especially in the PDY-I and PDY-II, are already heavily affected by organic pollution. Given the rapidly 
increasing population of Puducherry and the expected growth around the station, especially the proposed development around the estuary, the results from our study highlight the need for a more comprehensive survey over a prolonged period. A requirement of such work should include studying the pollution tolerance and behavior of many species within this area as this is largely unknown. This lack of essential knowledge currently hinders a more detailed assessment of the effects of pollution on the macrofauna community (Sundaray et al., 2006).

In conclusion, the Puducherry region on the coast, Tamil Nadu, India is a well known area for receiving large quantity of domestic sewage from adjacent urban areas and industrial wastes from the well developed industries. A significant discrimination of species composition was noticed on the benthic population between estuary (PDY-I and PDY-II) and coast (PDY-V and PDYVI) due to the differential in exposure by the macrobenthos for the pollutants. Macrobenthic fauna within the estuary follows the recognized trend of community change with increasing organic pollution, since some group of polychaete organinisms (Capitella capitata, Cossura coasta, Nephtys dibranchis and Nereis capensis) were found dominating. The same trend was confirmed through various statistical analyses. Hence, the present study recommends that the above polychaete species can be considered as indicator species for organic pollution. The estuary (PDY-I and PDY-II) is currently noticed with increasing trend of organic load as reflected in benthic population and also station PDY-III was very low diversity because continually disturbed with harbor developed so the bottom sediment was disturbed. Therefore, the present study insists that the stringent regulation mechanisms should be pursued for disposing the sewage in order to prevent the quality of the environment from deterioration.

\section{References}

Alexander, S.L., Berry, J., Colvin, T., Costley, S., Davis, D., Fletcher, M., Gaines, T.V., Hicks, D., Huffer, N., Jefferson, T., Murdock, T., Pindell, A., Stepney, S., Townsend, J., Vaughn, J., Yow, and Harris, P. 2007. Comparing the Macroinvertebrates from the three habitats at the savage river of Western Maryland.

Amar Musale, Desai, D.V. 2011. Distribution and abundance of macrobenthic polychaetes along the South Indian coast. pp178.

Armitage, P.D.D., Moss, J.F., Wright, and Furse, M.T. 1983. The performance of a new biological water quality score system based on macro invertebrates over a wide range of unpolluted running water sites. Freshwater Biological Association, River Laboratory, East Stoke, Wareham, Dorset BH20 6BB, England. 17(3): 333-347.

Barnes, R.D. 1980. Invertebrates Zoology, 4th Edition, Saunders College Publishing, Rinehart \& Wilnston, Philadelphia, pp 1089.

Bigot, L., Grémare, A., Amouroux, J.M., Frouin, P., Maire, O., Gaertner, J.C., 2008. Assessment of the ecological quality status of soft-bottoms in Reunion Island (tropical Southwest Indian Ocean) using AZTI marine biotic indices. Mar. Pollut. Bull., 56: 704-722. doi:10.1016/j.marpolbul.2007.12.020

Buchanan, J.B. 1984. Sediment analysis. In: Holme NA, McInyre AD. (eds), Blackwell scientific publications (Methods for the study of marine benthos), 2nd ed, 41-65. 
Clarke, K.R., Gorley, R.N. 2006. Primerv6UserManual/Tutorial. Primer-ELtd, Plymouth.

Damodaran, R. 1973. Studies on benthos of the mud banks of the Kerala coast. Bulletin of the Department of Marine Sciences University of Cochin, 6: $1-126$.

Day, J.H. 1967. A monograph on the Polychaeta of southern Africa. Trustees of British Museum (Natural History, London.

Fauvel, P. 1953. The fauna of India including Pakistan, Ceylon,Burma and Malaya. Allahabad: The Indian Press, 1953.

Gao. F., 2011. Ecological Characteristics of Macrobenthic Communities in the Chaohu Lake Basin and their Relationship with Environmental Factors.

Gaudette, H.E., Flight, W.R., Toner, L., Flolger, D.V. 1974. An in expensive titration method for determination of organic carbon in recent sediment. $J$. Sedimentary Petrol., 44: 249-253.

Gray, J.S. 1981.The Ecology of Marine Sediments: an Introduction to the Structure and Function of Benthic Communities. Cambridge University Press, Cambridge, pp185.

Hadley, D. 2015. Water Quality Monitoring Using Aquatic Macro invertebrates, What Aquatic Insects Can Tell You About the Quality of a Stream. Department of Environmental Resource Management, Lagos State University, Lagos, Nigeria.

Hily, C. 1984. Variabilite de la macrofaune benthique dans les milieux hypertrophiques de la Rade de Brest. Vol. 1-2. Thèse de Doctorat d'Etat, Université de Bretagne Occidendale, $337 \mathrm{pp}$.

Hyland, J., Balthis, L., Karakassis, I., Magni, P., Petrov, A., et al. 2005.
Organic carbon content of sediments as an indicator of stress in the marine benthos. Marine Ecol. Progress Series, 295: 91-103.

Ismail, N.S. 1992. Macrobenthic invertebrates near sewer outlets in Dubai creek, Arabian Gulf. Mar. Pollut. Bull., 24(2): 77-81.

Jenouvrier, S., Barbraud, C., Weimerskirch, H. 2003. Effects of climate variability on the temporal population dynamics of southern fulmars. J. Anim. Ecol., 72: 576-587.

Kailasam, M. 2004. Effect of thermal effluent discharge on benthic fauna off Tuticorin bay, south east coast of India, Indian J. Mar Sci., 33(2): 194201.

Kenney, M., A. Sutton-Grier, R. Smith, and S. Gresens. 2009. Benthic macroinvertebrates as indicators of water quality: The intersection of science and policy. Koninklijke Brill NV, Leiden 10.1163: 187-498.

Kindt, J.W. 1985. Solid Wastes and Marine Pollu., 34: 37.

Lyla, P.S., Velvizhi, S., Ajmal Khan, S. 1999. A monograph on the amphipods of Parangipettai coast. Annamalai University, India, pp 78.

Macdonald, T.B., Burd and A. van Roodselaar. 2012. Size structure of marine soft-bottom macrobenthic communities across natural habitat ingredients: implications for productivity and ecosystem function. PLos ONE, volume 7, issue 7

Magni, P. 2003. Biological benthic tools as indicators of coastal marine ecosystems health. Chemistry and Ecol., 19(5): 363-372.

Nkwoji, J.A., J.K. Igbo, A.O. Adeleye, J.A. Obienu, and M.J. Tony-Obiagwu. 2010. Implications of bioindicators in ecological health: study of A coastal lagoon, Lagos, Nigeria. Agri. Biol. J. 
North America, ISSN Print: 21517517, ISSN Online: 2151-7525.

O” ztu“rk, B., Kadıog`lu, M., O” ztürk, H., 2000. Marmara Sea 2000symposium report. In: O” ztu“rk, B., Kadioglu, M., O”ztu“rk, H. (Eds.), TU“ DAV Yayın no. 5, Istanbul.

Parulekar, A.H. \& Wagh, A.B. 1975. Quantitative studies on benthic macrofauna of north-eastern Arabian Sea shelf. Indian J. Marine Sci., 4: 174-176.

Pearson, T.H., Rosenberg, R. 1978. Macrobenthic succession in relation to organic enrichment and pollution of the marine environment. Oceanogr. Marine Biol., Annu. Rev., 16: 229311.

Rees, H.L., Sneddon, J., Boyd, S.E. 2005. Benthic Indicators: Criteria for Evaluating Scientific and Management Effectiveness 43.

Ruiz, F., Abad, M., Bodergat, A.M., Carbonel, P., Rodriguez-La'zaro, J., Yasuhara, M. 2005. Marine and brackish-water ostracods as sentinels of anthropogenic impacts. Earth-Sci. Rev., 72: 89-111.

Saravanakumar, A., Rajkumar, M., Sesh Serebiah, J., \& Thivakaran, G.A. 2008. Seasonal variations in physicochemical characteristics of water, sediment and soil texture in arid zone mangroves of Kachchh-Gujarat. $J$. Environ. Biol., 29: 725-732.

Satheeshkumar, P., Khan, A.B. 2011. Identification of mangrove water quality by multivariate statistical analysis methods in Pondicherry coast,
India. Environ. Monitoring and Assessment, DOI 10.1007/s10661011-2222-4.

Shine, J. \& Wallace, G. 2000. Chemical aspects of organic carbon and ecological stress in benthic ecosystems. p. 40- 44. In: Ad hoc Benthic Indicator Group-Results of Initial Planning Meeting. IOC Technical Series 57, 6-9 Decem ber 1999. UNESCO, Paris.

Smith, R., T. Smith. 2006. "Elements of Ecology" BenjaminCummings Publishing Co, 6th ed.

Sundaray, S.K., Panda, U.C., Nayak, B.B., Bhatta, D. 2006. Multivariate Statistical Techniques for the Evaluation of Spatial and Temporal Variation in Water Quality of the Mahanadi River-Estuarine System (India)-A Case Study, Environ. Geochemistry and Health, 28(4): 317330.

Tagliapietra, D. and M. Sigovini. 2010. Benthic fauna: collection and identification of macrobenthic invertebrates. Terre et Environ., 88: 253-261.

Venturini, N., Tommasi, L.R., Bicego, M.C., Martins, C.C. 2004. Characterization of the benthic environment of a coastal area adjacent to an oil refinery, Todos Os santos Bay (NE-Brazil). Brazilian J. Oceanography, 52(2): 123-134.

Wu, M.L., Wang, Y.S., Sun, C.C., Wang, H.L., Dong, J.D. 2009. Using chemometrics to identify water quality in Day Bay, China. Oceanologia, 52: 217-232.

\section{How to cite this article:}

Balachandar, K., A. Sundaramanickam and Kumaresan, S. 2016. Spatial and Seasonal Variation of Macrobenthos from Puducherry Coast, Southeast Coast of India. Int.J.Curr.Microbiol.App.Sci. 5(10): 33-49. doi: http://dx.doi.org/10.20546/ijcmas.2016.510.006 